Edutainment : Jurnal Ilmu Pendidikan dan Kependidikan

Volume 8 Nomor 2 Edisi Juli - Desember 2020

\title{
MANAJEMEN KURIKULUM PENDIDIKAN AGAM ISLAM BERBASIS PERILAKU SISWA SD
}

\author{
Adi Saputra \\ Universitas Muhammadiyah Bangka Belitung \\ adi.saputra@stkipmbb.ac.id
}

\begin{abstract}
Abstrak
Penelitian ini bertujuan untuk mengetahui Manajemen Kurikulum Pendidikan Agama Islam dan berbasis perilaku siswa di SD IT Al Bina Kota Pangkalpinang. Metode penelitian ini merupakan penelitian kualitatif dimana peneliti mengamati dan partisipasi secara langsung dalam sekala sosial kecil dan mengamati budaya setempat. Manajemen Kurikulum Pendidikan Agama Islam berbasis perilaku di SD IT Al Bina disana secara umum mencakup beberapa kegiatan utama dari perencanaan, pengorganisasian, pelaksanaan, dan evaluasi. Hasil penelitian menunjukan bahwa: (1) perencanaan kurikulum pendidikan agama islam menggunakan acuan kurikulum 2013. Desain kurikulum pendidikan agama islam menekankan pada pengalaman pembelajaran. (2) kurikulum pendidikan agama islam dikelompokan dalam beberapa bidang, yakni akidah, akhlak, Qur'an dan hadis, fiqih, sejarah islam dan bahasa Arab. (3) pelaksanaan kurikulum PAI melibatkan peran kepala sekolah, guru, rencana pelaksanaan pembelajaran berkarakter, pembiasaan dan keteladanan, serta kegiatan ekstrakurikuler. (4) evaluasi pembelajaran yang digunakan yaitu penilaian proses dengan mengamati aktivitas siswa dan penilaian tugas (portofolio) serta memantau keberhasilan pembelajaran siswa di kelas.
\end{abstract}

Kata Kunci: Manajemen; kurikulum; pendidikan agama Islam; Prilaku.

\begin{abstract}
This study aims to determine the Management of Islamic Education Curriculum and behaviorbased students in Al IT Bina Elementary School, Pangkalpinang City. This research method using field studies is a qualitative research in which researchers observe and participate directly in small social scales and observe local culture. The management of the behavior-based Islamic Religious Education curriculum at SD IT Al Bina there generally includes several main activities from planning, organizing, implementing, and evaluating. The results showed that: (1) Planning of Islamic education curriculum using of KTSP curriculum. The design of Islamic education curriculum emphasizes learning experience. (2) The organizing of Islamic Religious Education curriculum is grouped into several fields: theology, morals, Qur'an and Hadith, fiqh, Islamic history, and Arabic language. (3) The implementation of PAI curriculum involves the role of principals, teachers, character based lesson plans, habituation and exemplary, as well as extracurricular activities. (4) Evaluation of learning used is the assessment process by observing student activities and assessment of the task (portfolio) and monitor the success of learning in the classroom.
\end{abstract}

Keywords: Manajemen; kurikulum; pendidikan agama Islam; Prilaku. 
Edutainment : Jurnal Ilmu Pendidikan dan Kependidikan

Volume 8 Nomor 2 Edisi Juli-Desember 2020

\section{PENDAHULUAN}

Manajemen kurikulum pendidikan agama islam merupakan proses penggunaan sumber daya secara efektif untuk mencapai sasaran dalam mengelola sejumlah mata pelajaran yang harus ditempuh dan diselesaikan anak didik untuk memperoleh ijazah dengan nuansa yang didasarkan pada nilai-nilai ajaran islam, sebagaimana yang tercantum dalam Al-Quran dan Al-Hadist serta dalam pemikiran para ulama dalam praktik sejarah umat islam.

Manajemen kurikulum pendidikan islam memiliki ciri-ciri tertentu. Ciri-cirinya sebagai berikut: (1) Menonjolkan tujuan agama dan akhlak pada berbagai tujuan, kandungan, metode, alat, dan tekniknya. (2) Memiliki keseimbangan antara kandungan kurikulum dari segi ilmu dan seni, kemestian, pengalaman, dan kegiatan pengajaran yang beragam. (3) Memiliki perhatian yang luas dan kandungan yang menyeluruh. Maksudnya ialah aspek pribadi siswa tepat pada sasaran terutama aspek pribadi siswa, yakni jasmani, akal, dan rohani. (4) Berkecenderungan pada seni halus, aktivitas pendidikan jasmani, latihan militer, pengetahuan teknik, latihan kejuruan, dan bahasa asing untuk perorangan maupun bagi mereka yang memiliki kesediaan, bakat, dan keinginan. (5) Keterkaitan kurikulum dengan kesediaan, minat, kemampuan, kebutuhan, dan perbedaan perorangan di antara mereka (Qomar, 2007).

Dalam Undang-undang Nomor 20 Tahun 2003 tentang Sistem Pendidikan Nasional disebutkan bahwa "Pendidikan nasional berfungsi mengembangkan kemampuan dan membentuk watak serta peradaban bangsa yang bermartabat dalam rangka mencerdaskan bangsa yang bermartabat dalam rangka mencerdaskan kehidupan bangsa, bertujuan untuk berkembangnya potensi peserta didik agar menjadi manusia yang beriman dan bertakwa kepada Tuhan Yang Maha Esa, berakhlak mulia, sehat, berilmu, cakap, kreatif, mandiri, dan menjadi warga negara yang demokratis serta bertanggung jawab" (Pasal 3). Potensi peserta didik yang akan dikembangkan, seperti beriman, bertakwa kepada Tuhan Yang Maha Esa, berakhlak mulia, sehat, berilmu, cakap, kreatif, mandiri, dan menjadi warga negara yang demokratis, serta bertanggung jawab pada hakikatnya sangat dekat dengan makna karakter. Pengembangan potensi tersebut selanjutnya menjadi landasan implementasi pendidikan karakter di Indonesia.

Sedangkan manajemen secara fungsional merupakan kegiatan yang terdiri dari perencanaan (Planning), 
Edutainment : Jurnal Ilmu Pendidikan dan Kependidikan

Volume 8 Nomor 2 Edisi Juli - Desember 2020

pengorganisasian (organizing) yang didalamnya terdapat penepatan struktur organisasi, pengisian orang-orang yang akan mengisi struktur tersebut yang selanjutnya dikenal dengan sebagai staffing.

Sejak akhir abad ke-19, ilmuwan manajemen sepakat mendefinisikan manajemen dengan empat fungsi manajemen yang dikenal dengan classical management functions: merencanakan (planning), mengorganisasi (organizing), memimpin (leading), dan mengendalikan (controlling). Walaupun kerap diperdebatkan, keempat fungsi manajemen klasik tersebut umumnya diterima sampai saat ini. Manajemen adalah proses merencana, mengorganisasi, memimpin, dan mengendalikan upaya semua anggota organisasi dan berbagai sumber daya organisasi lainnya untuk mencapai berbagai sasaran yang telah ditetapkan (Satyagraha, 2013).

Kesimpulan bahwa tujuan merupakan hal terjadinya proses manajemen dan aktivitas kerja, tujuan beraneka macam, tetapi harus ditetapkan secara jelas, realistis, dan cukup menantang berdasarkan analisis data, informasi, dan pemilihan dari alternatif-alternatif yang ada. Kecakapan manajer dalam menetapkan tujuan dan kemampuannya memanfaatkan peluang, mencerminkan tingkat hasil yang dapat dicapainya. Perlu diketahui dan dihayati bahwa intisari manajemen yaitu mencapai tujuan yang optimal dengan meningkatkan daya guna serta hasil guna dari potensipotensi yang dimilikinya.

\section{METODE PENELITIAN}

Metode penelitian yang digunakan dalam penelitian ini yaitu penelitian lapangan (field research). Menurut Bailey (1994) penelitian dengan cara terjun langsung ke tempat penelitian untuk mengamati dan terlibat langsung dengan objek penelitiannya. Sedangkan jenis penelitiannya yaitu penelitian kualitatif yang mana penelitian ini memiliki karakteristik bahwa data-datanya dikatakan dalam keadaan sewajarnya sebagaimana adanya.

Menurut Patton (2002) melalui studi penelitian lapangan dengan teknik observasi dan wawancara serta interview dengan stakeholder.

Metode ini dipakai dalam upaya memahami dan memberikan analisis tentang objek penelitian. Dengan metode penelitian ini diharapkan akan terungkap gambaran mengenai realitas sasaran penelitian, yakni tentang manajemen kurikulum pendidikan agama Islam untuk memperbaiki karakter peserta didik. 
Edutainment : Jurnal Ilmu Pendidikan dan Kependidikan

Volume 8 Nomor 2 Edisi Juli-Desember 2020

\section{HASIL DAN PEMBAHASAN}

Manajemen kurikulum Pendidikan Agama Islam pada SD IT Al Bina Kota Pangkalpinang secara umum mencakup beberapa kegiatan utama dari perencanaan, pengorganisasian, pelaksanaan, dan evaluasi.

\section{Perencanaan Kurikulum Pendidikan} Agama Islam

Perencanaan merupakan proses penyusunan sesuatu yang akan dilaksanakan untuk mencapai tujuan yang ditentukan. Kurikulum pendidikan Agama Islam di SD IT Al Bina menggunakan kurikulum KTSP dari kementrian Agama. Kurikulum Tingkat Satuan Pendidikan SD IT Al Bina UPT Dinas Pendidikan Kota Pangkalpinang, dikembangkan sebagai perwujudan dari kurikulum pendidikan dasar dan menengah. Kurikulum ini disusun oleh satu tim penyusun yang terdiri atas unsur sekolah dan komite sekolah di bawah koordinasi dan supervisi Kepala Dinas Pendidikan Kota, serta dengan bimbingan narasumber dari Tim Bimbingan Teknis Pengembangan KTSP Pendidikan Dasar, Pusat Kurikulum, Balitbang Depdiknas.

Pengorganisasian Kurikulum Pendidikan

\section{Agama Islam}

Kurikulum mata pelajaran Pendidikan Agama Islam di SD IT Al Bina dikelompokkan dalam beberapa bidang studi antara lain: Akidah, Akhlak, Quran dan Hadits, Fiqih, Sejarah Islam, Bahasa Arab. Dari semua bidang studi ada yang bertanggung jawab atas kelompok bidang studi agama ini dan guru diharuskan mengumpulkan buku-buku penunjang dan buku utama yang akan digunakan sebagai pegangan dalam mata pelajaran Agama di kelas. Program pendidikan yang digunakan yaitu Sistem Paket, yakni mewajibkan siswa (peserta didik) mengikuti seluruh program pembelajaran, beban belajar yang dibebankan untuk setiap kelas sesuai dengan Struktur Kurikulum, yang dinyatakan dalam satuan jam pembelajaran termasuk muatan sekolah disesuaikan dengan kebutuhan.

\section{Pelaksanaan Kurikulum Pendidikan Agama Islam}

Fungsi manajemen selanjutnya yaitu pelaksanaan meliputi pengarahan dan bimbingan sebagai perwujudan fungsi manajemen. Fungsi pelaksanaan yaitu kegiatan pelaksanaan untuk mengetahui kelemahan dan keberhasilan. Pengarahan yaitu memberikan stimulasi kepada guru. Dalam pengarahan ini guru diarahkan dalam pengembangan silabus membuat RPP dan cara mengajar di kelas supaya dapat sesuai rencana serta dapat menciptakan suasana kondusif, sehingga pembelajaran dapat 
Edutainment : Jurnal Ilmu Pendidikan dan Kependidikan

Volume 8 Nomor 2 Edisi Juli-Desember 2020

berjalan dengan efektif dan efisien. Guru Agama juga memberikan pengarahan yang baik kepada siswanya dalam tingkah laku saat pembelajaran di kelas maupun saat belajar di luar kelas dengan menanamkan nilai-nilai Islam dalam pembelajaran di kelas. SD IT Al Bina juga melakukan pelatihan-pelatihan untuk guru sebagai sarana untuk memberikan pengarahan terhadap guru, sehingga guru dapat melakukan pembelajaran di kelas secara kondusif efisisen serta untuk mengetahui keberhasilan dan kelemahan sekolah terutama pemanfaatan media yang ada.

\section{Evaluasi Kurikulum Pendidikan Agama}

\section{Islam}

Terkait dengan pelaksanaan penilaian SD IT Al Bina ada evaluasi berkaitan dengan perangkat pembelajaran juga evaluasi saat pembelajaran dilaksanakan 1 bulan sekali. Sedang evaluasi yang diberikan guru kepada siswa yaitu evaluasi proses belajar mengajar dan evaluasi hasil belajar keseluruhan dari proses belajar mengajar oleh peserta didik. Jenis-jenis evaluasi yang digunakan SD IT Al Bina yaitu penilaian proses dengan mengamati aktifitas siswa dan penilaian tugas (portofolio) serta memantau keberhasilan KBM di kelas dengan meningkatkan dan menerapkannya di kelas, sehingga dapat mencapai visi dan misi sekolah. Dengan adanya evaluasi guru Agama dapat mengetahui tingkat keberhasilan dalam pembelajaran di kelas.

Keberhasilan pembelajaran PAI di sekolah salah satunya juga ditentukan oleh penerapan metode pembelajaran yang tepat. Menurut Ulwan (2012) dalam buku "Tarbiyatul Aulad Fil Islam" memberikan Konsep pendidikan influentif dalam pendidikan akhlak anak yang terdiri dari: 1) Pendidikan dengan keteladanan, 2) Pendidikan dengan adat kebiasaan, 3) Pendidikan dengan nasihat, 4) Pendidikan dengan memberikan perhatian, 5) Pendidikan dengan memberikan hukuman (Ainiyah, 2013).

Pendapat di atas menggambarkan bahwa akhlak merupakan pilar utama dari tujuan dari tujuan pendidikan di dalam Islam, hal ini senada dengan latar belakang perlunya diterapkan pendidikan karakter di sekolah; untuk menciptakan bangsa yang besar, bermartabat dan disegani oleh dunia, maka dibutuhkan good society yang dimulai dari pembangunan karakter (character building). Pembangunan karakter atau akhlak tersebut dapat dilakukan salah satunya melalui proses pendidikan di sekolah dengan mengimplementasikan penanaman nilai-nilai akhlak dalam setiap materi pembelajaran. 
Edutainment : Jurnal Ilmu Pendidikan dan Kependidikan

Volume 8 Nomor 2 Edisi Juli-Desember 2020

Menunjukkan keteladanan merupakan metode yang wajib dilakukan dalam memperbaiki karakter anak. Pendidik baik orang tua maupun guru mampu menunjukkan perilaku yang sesuai dengan nasihat atau atribut karakter yang ingin dibentuk dalam diri anak. Rasulullah SAW menunjukkan keteladanan dalam melaksanakan ajaran Islam yang terdapat dalam Alquran.

Keteladanan dari orang tua dan guru sangat dibutuhkan dalam membentuk kepribadian anak, sehingga menjadi muslim yang berkarakter. Tujuan pendidikan Islam adalah menjadikan setiap muslim agar menjadi pribadi yang berakhlak sesuai dengan akhlak Alquran dan sunah. Jika pendidikan berhasil dilakukan, anak akan menjadi manusia yang berkepribadian Islami yang segala perbuatan, lisan, ilmu pengetahuan, dan seluruh aspek kehidupannya mencerminkan perilaku yang Islami.

Oleh sebab itu, lingkungan sekolah dapat menjadi tempat pendidikan yang baik bagi pertumbuhan karakter siswa. Segala peristiwa yang terjadi di dalam sekolah semuanya dapat diintegrasikan dalam program pendidikan karakter. Dengan demikian pendidikan karakter merupakan sebuah usaha bersama dari seluruh warga sekolah untuk menciptakan sebuah kultur pendidikan karakter.

Secara fitrah setiap anak mempunyai potensi untuk taat kepada Allah SWT, sebagaimana firman Allah: Dan (ingatlah) ketika Tuhanmu mengeluarkan dari sulbi (tulang belakang) anak cucu Adam keturunan mereka dan Allah mengambil kesaksian terhadap roh mereka (seraya berfirman), "Bukankah Aku ini TuhanMu?" Mereka menjawab, "Betul (Engkau Tuhan kami), kami menjadi saksi." (Kami lakukan yang demikian itu) agar di hari kiamat kamu tidak akan mengatakan, "Sesungguhnya ketika itu kami lengah terhadap ini” (Q. S. Al-Araf: 172).

Ayat tersebut menyatakan bahwa fitrah setiap anak untuk mengakui Allah sebagai tuhan dan taat kepada-Nya. Akan tetapi, anak dapat saja tidak menjalankan hal tersebut selama dia belum melihat orang tua atau gurunya memberikan contoh yang baik dalam menjalankan ketaatan kepada Allah. Anak akan tumbuh menjadi pribadi yang beriman, memiliki akhlak yang Islami, dan kepribadian muslim jika diberikan pendidikan Islami dan hidup dalam lingkungan Islami. Lingkungan Islami akan menempa anak untuk terbiasa menjalankan perilaku Islami. Hal tersebut dikarenakan seorang anak akan bertingkah laku sesuai 
Edutainment : Jurnal Ilmu Pendidikan dan Kependidikan

Volume 8 Nomor 2 Edisi Juli - Desember 2020

dengan apa yang sering dilihat dan didengarnya dari lingkungannya. Oleh sebab itu, faktor yang paling utama dalam membentuk kebiasaan bagi seorang anak yaitu dengan mencontoh kebiasaan yang dilakukan oleh orang tua, teman, dan anggota masyarakat yang dilihatnya.

Penerapan pembiasaan di SD IT Al Bina merupakan salah satu lembaga pendidikan yang dapat menciptakan sebuah pendekatan pendidikan karakter melalui kurikulum, penegakkan disiplin, manajemen kelas, maupun melalui program-program pendidikan lain yang dirancang, seperti ekstrakurikuler.

Adapun kendala yang dihadapi di SD IT Al Bina salah satunya yaitu ketidaksesuaian antara perencanaan dengan pelaksanaan kurikulum pendidikan agama Islam, hal ini menyebabkan kurang maksimalnya dalam pengaplikasian pembelajaran pendidikan agama Islam di lapangan.

Jadi, instrumen input menentukan tingkat dari keberhasilan mutu pendidikan agama Islam terlebih jika dikorelasikan dengan proses pendidikan tersebut. Meminjam konsep berpikir manajemen sistem industri modern, maka manajemen mutu terpadu pada lembaga pendidikan Islam seyogianya memandang bahwa proses pendidikan mutu terpadu yaitu suatu peningkatan terus-menerus (continuous educational process improvement), yang dimulai dari sederet siklus sejak adanya ideide untuk menghasilkan lulusan (output) yang berkualitas, pengembangan kurikulum, proses pembelajaran, dan ikut bertanggung jawab untuk memuaskan pengguna lulusan dari lembaga pendidikan Islam tersebut. Seterusnya, berdasarkan informasi sebagai umpan-balik yang dikumpulkan dari pengguna lulusan (external customers) itu dapat dikembangkan ide-ide kreatif untuk mendesain ulang kurikulum atau memperbaiki proses pendidikan yang ada pada saat ini (Sukarji dan Umiarso, 2014).

Namun objek dalam lingkungan sekolah, yakni peserta didik itu sendiri. Dalam menumbuhkan karakter peserta didik, peran orang tua dibutuhkan sebagai bentuk kepedulian terhadap penyelenggaraan pendidikan Islam, seperti halnya selalu mengingatkan dan peduli pada proses belajar peserta didik di rumah maupun di sekolah. Hal ini merupakan faktor penyokong terhadap peningkatan mutu pendidikan agama Islam.

Ada beberapa cara dalam pelaksanaan kurikulum pendidikan berbasis karakter mata pelajaran Pendidikan Agama Islam (PAI) di SD IT Al Bina, yakni Pertama, dintegrasikan dalam mata pelajaran yang secara dokumen 
Edutainment : Jurnal Ilmu Pendidikan dan Kependidikan

Volume 8 Nomor 2 Edisi Juli-Desember 2020

dimasukkan ke dalam silabus dan Rencana Program Pembelajaran (RPP). Kedua, diintegrasikan ke dalam muatan lokal yang sudah ditentukan oleh sekolah. Ketiga, diintegrasikan ke dalam kegiatan pengembangan diri yang meliputi ekstrakurikuler serta pembiasaanpembiasaan. Paparan di atas diperkuat dengan pendapat Bapak Ansori S.Pd.I selaku Kepala Sekolah SD IT Al Bina yang mengatakan

"Kita sisipkan/masukkan/integrasikan pada materi mata pelajaran Pendidikan Agama Islam (PAI) yang sesuai dengan nilai karakter yang diharapkan seperti contoh yang sudah saya paparkan di atas tadi, pelaksanaannya seperti itu. Jadi tidak terdiri dalam jam sendiri/kurikulum sendiri, namun kita integrasikan pada materi mata pelajaran yang sudah ada. Selain itu juga bisa melalui ekstrakurikuler, muatan lokal, misalnya berlangsungnya kegiatan tahfidzul qur'an setiap pagi. Juga bisa melalui pengembangan diri, sebagai contoh, memberi salam, bersalaman, berdoa sebelum dan sesudah aktivitas, dan lain-lain. Jadi pelaksanaannya dapat dilakukan di dalam kelas maupun di luar kelas serta di lingkungan masyarakat”.

Petikan wawancara dapat disimpulkan bahwa cara mengintegrasikan pembelajaran Pendidikan Agama Islamdi SD IT Al Bina adalah dengan melihat dari silabus yang sudah diterapkan mulai dari SK, KD dan menentukan indikator dan tujuan yang ingin dicapai sesuai dengan materi pembahasan. Semuanya bisa langsung dicantumkan di dalam silabus, RPP yang sudah dibuat oleh guru PAI.

Hasil temuan peneliti bahwa di SD IT Al Bina telah menerapkan pendidikan berbasis karakter sesuai dengan himbauan pemerintah melalui Undang-Undang Nomor 20 Tahun 2003 tentang Sistem Pendidikan Nasioanl Pasal 3 bukan hanya secara dokumen, tetapi sudah terlaksana secara tindakan. Hal itu sudah terbukti dengan adanya dokumen tertulis dalam kurikulum yang didalamnya disisipkan nilai-nilai karakter, sedang dalam aplikasinya jelas tercermin dari kegiatan sehari-hari yang ada di dalam sekolah mulai dari pembiasaan rutin, spontan, dan terprogram. Berdasarkan kondisi sekolah dan rapat dewan guru serta mempertimbangkan kondisi dan kebutuhan siswa di SD IT Al Bina terdapat kegiatan pengembangan diri yang dipilih dan ditetapkan.

Hal tersebut berkaitan dengan pembentukkan karakter peserta didik sehingga mampu bersaing, beretika, bermoral, sopan santun dan berinteraksi dengan masyarakat. Berdasarkan penelitian, 
Edutainment : Jurnal Ilmu Pendidikan dan Kependidikan

Volume 8 Nomor 2 Edisi Juli-Desember 2020

ternyata kesuksesan seseorang tidak ditentukan semata-mata ilmu pengetahuan dan kemampuan teknis (hard skill) saja, tetapi kemampuan mengelola diri (soft skill).

Melalui kegiatan ekstrakurikuler diharapkan dapat mengembangkan kemampuan dan rasa tanggung jawab sosial, serta potensi dan prestasi peserta didik. Namun, pendidikan karakter sangat terkait dengan manajemen atau pengelolaan sekolah itu sendiri, yakni pendidikan karakter direncanakan, diorganisasikan, dilaksanakan, dikendalikan dalam kegaiatankegiatan pendidikan di sekolah secara memadai.

\section{SIMPULAN DAN SARAN}

Simpulan penelitian ini, yakni 1) Perencanaan kurikulum pendidikan Agama Islam di SD IT Al Bina menggunakan acuan kurikulum KTSP dari kementrian Agama. Dalam penyusunan kurikulum PAI berbasis karakter di SD IT Al Bina mengacu pada empat hal substansif yang menjadi perhatian, yakni pendidikan karakter, struktur kurikulum, media pembelajaran, dan alokasi anggaran. Desain kurikulum PAI di SD IT Al Bina dengan menekankan pemahaman pembelajaran pengalaman. Pemilihan dalam pembelajaran berbasis tema, SD IT Al Bina memadukan kurikulum di bawah tema besar, sehingga peserta didik dapat mempelajari berbagai disiplin ilmu. 2) Pengorganisasian kurikulum mata pelajaran Pendidikan Agama Islam di SD IT Al Bina dikelompokkan dalam beberapa bidang studi antara lain: Akidah, Akhlak, Quran dan Hadits, Fiqih, Sejarah Islam, Bahasa Arab. Dari semua bidang studi ada yang bertanggung jawab atas kelompok bidang studi agama ini dan guru diharuskan mengumpulkan buku-buku penunjang dan buku utama yang akan digunakan sebagai pegangan dalam mata pelajaran Agama di kelas. Program pendidikan yang digunakan yaitu Sistem Paket, yakni mewajibkan siswa (peserta didik) mengikuti seluruh program pembelajaran, beban belajar yang dibebankan untuk setiap kelas sesuai dengan Struktur Kurikulum, yang dinyatakan dalam satuan jam pembelajaran termasuk muatan sekolah disesuaikan dengan kebutuhan. 3) Pelaksanaan kurikulum PAI berbasis karakter di SD IT Al Bina mengedepankan pelaksanaan pada: 1. peran kepala sekolah dalam tataran sekolah, 2. peran guru dalam tataran kelas, 3. Rencana Pelaksanaan Pembelajaran (RPP) berkarakter, 4. pembiasaan keteladanan, dan 5. kegiatan ekstrakurikuler. 4) Evaluasi kurikulum PAI untuk memperbaiki karakter peserta didik di SD IT Al Bina mencakup empat aspek di antaranya: aspek guru, berkenaan dengan 
Edutainment : Jurnal Ilmu Pendidikan dan Kependidikan

Volume 8 Nomor 2 Edisi Juli - Desember 2020

metode pembelajaran, aspek siswa berkenaan dengan nilai perkembangan siswa, dan aspek orang tua, berkenaan dengan dukungan dari orang tua terhadap putra putrinya sehubungan dengan informasi yang diberikan sekolah melalui buku penghubung (raport).

Sementara saran penelitian ini, yakni 1) Bagi Sekolah, Sekolah hendaknya terus berupaya mendukung Program manajemen kurikulum PAI yang dilakukan oleh sekolah. 2) Bagi guru, guru diharapkan lebih Baik dalam menerapkan manajemen kurikulum PAI. Serta senantiasa berupaya untuk tetap dan terus meningkatkan kualitas diri dalam menjadi role model bagi warga sekolah.

\section{DAFTAR PUSTAKA}

Ainiyah, N. (2013). Jurnal Al-Ulum, 13(1), 25-38.

Bailey, K. D. (1994). Methods of Social Reseach. New York: The Free Press.

Qomar, M. (2007). Manajemen Pendidikan Islam (Strategi Baru Pengelolaan Lembaga Pendidikan Islam). Jakarta: Erlangga.

Patton, M. Q. (2002). Qualitative Research and Evaluation Methods. California: Sage Publications.

Quran. Bandung: Simbiosa Rekatama Media.

Satyagraha, H. (2013). The Case Method: Mendidik Manajer Ala Harvard. Jakarta: Erlangga.

Sukarji, \& Umiarso. (2014). Manajemen dalam Pendidikan Islam (Rekonstruksi Teoritis dalam Menemukan Kebermaknaan Pengelolaan Pendidikan Islam. Jakarta: Mitra Wacana Media.

Ulwan, A. N. (2012). Tarbiyatul Aulad Fil Islam. Solo: Insan Kamil. 